\title{
Smart lighting system control strategies for commercial buildings: a review
}

\author{
N. H. Baharudin ${ }^{1 *}$, T. M. N. T. Mansur ${ }^{3}$, R. Ali ${ }^{2}$ and N. F. A. Sobri ${ }^{1}$ \\ Faculty of Electrical Engineering Technology, Universiti Malaysia Perlis, Malaysia ${ }^{1}$ \\ Centre of Excellence for Renewable Energy (CERE), Universiti Malaysia Perlis, Malaysia ${ }^{2}$ \\ Centre of Sustainable Campus and Energy Management, University Malaysia Perlis, Malaysia ${ }^{3}$
}

Received: 20-October-2020; Revised: 23-January-2021; Accepted: 25-January-2021

C2021 N. H. Baharudin et al. This is an open access article distributed under the Creative Commons Attribution (CC BY) License, which permits unrestricted use, distribution, and reproduction in any medium, provided the original work is properly cited.

\begin{abstract}
Rapid global economic growth and growing population have tremendously led to the increasing demand for energy needs in commercial and residential buildings. The main energy resources for electrical energy generation in Malaysia are fossil fuels. The increase in electricity demands causes simultaneous proportional growth in fossil fuel consumption, thereby leads to higher greenhouse gas emissions. Buildings have emerged as the most voracious electrical energy consumer which contributes over one-third of global energy consumption. Furthermore, lightings and air-conditioning systems have the most significant impacts on the total electricity usage of buildings in Malaysia. Thus, energy efficiency efforts targeting both loads will significantly reduce total energy consumption in the buildings. This paper aimed at reviewing energy efficiency efforts at the commercial buildings and comparison between simple strategy and SMART Building by using Building Energy Management System (BEMS). Many aspects of energy efficiency efforts will be considered such as energy consumption, occupant comfort, and system cost. Furthermore, suggestions for improving energy efficiency in the commercial building using the best strategy to reduce energy consumption by using a lighting control system will be discussed.
\end{abstract}

\section{Keywords}

Lighting, Energy consumption, Lighting control system, Occupant, Smart building.

\section{Introduction}

Buildings and construction industry together are responsible for $39 \%$ of global energy-related carbon dioxide (CO2) emissions, with $28 \%$ are used directly to provide convenient, well-lit residential, commercial, and industrial buildings through space conditioning and lightings [1]. This is due to buildings such as residential, schools, universities, offices, healthcare, and industrials that have become critical consumers in energy consumption for economic growth. On the other hand, the impact of the Covid-19 outbreak on electricity demand for residential buildings has increased by $40 \%$ due to lockdown measures since more people are staying at homes and undertaking additional activities at home, such as online learning, teleconferencing, and remote work from home [2]. Sectoral electricity consumption in Malaysia has greatly increased from 1978 until 2018 as presented in Figure 1.

*Author for correspondence

45
This is due to the development of commercial buildings and residential area projects which has immensely increased over the last three decades. This tremendous expansion has a great impact on economic growth and energy demand in Malaysia ever since [3, 4]. In 2018, commercial and residential buildings consumed $49.5 \%$ of Malaysia's total energy consumption which is skyrocketed by more than $2217 \%$ since 1978. Commercial and residential buildings consumed 3958 ktoe and 2553 ktoe respectively which is accounted for $6511 \mathrm{ktoe}$. This is approximately equivalent to the energy consumption of the industrial sector about 6547 ktoe. Buildings development will continue to expand with unprecedented rates for economic sustainability. Consequently, buildings have become the major single largest contributor to global warming which contributes to one-third of global carbon emissions [1].

Malaysia particularly has emitted 250.3 million tonnes of $\mathrm{CO} 2$ in 2018 as compared to 241.6 million tonnes in 2017. The growth in $\mathrm{CO} 2$ emission is 
directly linked with energy demand. The main causes of the $\mathrm{CO} 2$ emissions come from the consumption of fossil fuels for electricity generation mainly from commercial and residential buildings, transportations, as well as municipal solid waste landfills [5]. In mitigating climate change and global warming issues, Malaysia has introduced the Green Technology Master Plan (GTMP) 2017-2030 to reduce CO2 emissions per unit of the nation's Gross Domestic Product (GDP) by 2030 [6]. GTMP aims at two main subsectors of renewable energy (RE) and energy efficiency (EE) in achieving the $\mathrm{CO} 2$ reduction target [7-9]. The on-going EE initiative is National Energy Efficiency Action Plan (NEEAP) to strategize successful coordination and cost-efficient energy efficiency efforts for industrial, commercial, and residential sectors, which will reduce energy consumption and direct monetary saving benefit to the nation and consumers. Energy audits and energy management in buildings and industries are the key initiatives under NEEAP with an expected electricity saving of 34,832 GWh by 2025 [10]. Energy audits are conducted to identify potential energy savings without compromising on human comfort, health, and safety. Energy-saving measures can be implemented through no-cost practices which can be done immediately without incurring any cost and low-cost practices. Even though these practices do not involve any heavy investments, but they can have a significant impact that can achieve $5 \%$ or more energy savings. An example of the no-cost energysaving practice is through operation and maintenance such as turn-off lights whenever they are not needed. The modern lightings are designed to withstand frequent turning on and off rather than switching it on all the time. This simple behavior adjustment has high potentials in which it can offer immediate energy savings [11]. Lightings alone in commercial buildings are accounted for $17 \%$ of US total electricity consumption and it becomes the secondlargest end-user of electricity [12]. On the other hand, the percentage of end-user electricity distribution for typical commercial buildings in Malaysia is presented in Figure 2. Lightings are the next largest electricity end-user by $20 \%$ after air-conditioning load for about $58 \%$, followed by office equipment and others of $22 \%$ [13].

Due to the importance of lighting in building for the requirement of visual comfort and energy efficiency measure, lighting energy management should provide the optimal lighting level for the occupants to complete their jobs with the most efficient lighting source suitable for the job whenever and wherever required [14]. Current lighting control systems depend on occupants' manual control over lighting for switching on and off. However, occupants tend to forget turning off the lights when leaving the room due to occupants' behavior and lack of awareness for energy-saving practices. The lightings are left on continuously even no occupants' activities in the building have led to energy waste and unnecessary burden due to high electricity bills [15]. Inconsistency of occupants' behavior towards energy-saving practices is one of the difficulties in achieving energy-efficient buildings [16]. Thus, lighting control strategies are vital in reducing building energy consumption which can achieve more than $50 \%$ energy savings [17].

Instead of retrofitting the lightings with more energyefficient lightings such as LED, T8, and T5 lamps [18], the deployment of building lighting control strategies have shown more significant energy savings potential [19]. Current building lighting control system can be developed with installation of switches, dimmers and scene setters, time scheduling, group control, occupancy adaptation, daylight harvesting, personal control, demand response, and combination of occupancy and daylight adaptation. Besides, advanced smart control strategies as depicted in Figure 3 are wireless distributed lighting control system, power-over-ethernet (POE) centralized lighting control system [20]. Examples of the communication systems and protocols for advanced lighting control systems are Digital Addressable Lighting Interface (DALI) and Digital Multiplexing (DMX) 512/1990 [14]. According to sustainable development, recent buildings particularly smart buildings have employed building energy management systems (BEMS) using the Internet of Things (IoT) and it becomes more popular in commercial buildings [21-23]. By using the BEMS, buildings' energy consumption can be easily monitored and controlled. BEMS is designed to detect any abnormalities in electrical energy utilization, then adjusted and re-analyzed the strategies for the control system to ensure occupants' comfort while being energy-efficient buildings [21, 24]. The objectives of this paper are to present an insight of current trends and future challenges of lighting control strategies and provide recommendations to reduce electrical energy consumption for buildings. The comparative analysis and discussions of the applications and limitations for current and future trends of lighting control strategies are summarized to support the investigation for successful smart building lighting systems. 


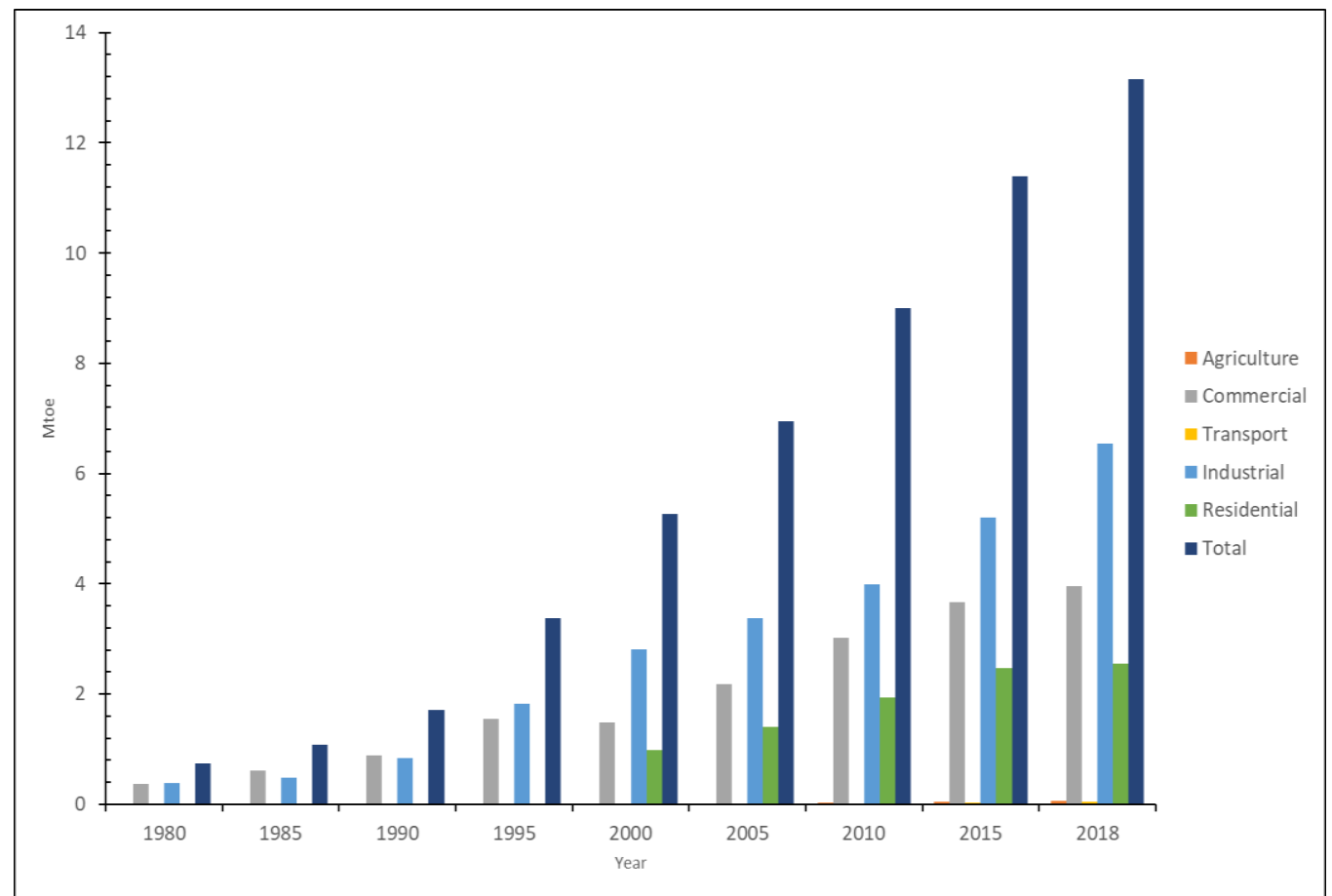

Figure 1 Sectoral electricity consumption in Malaysia from 1978 until 2018
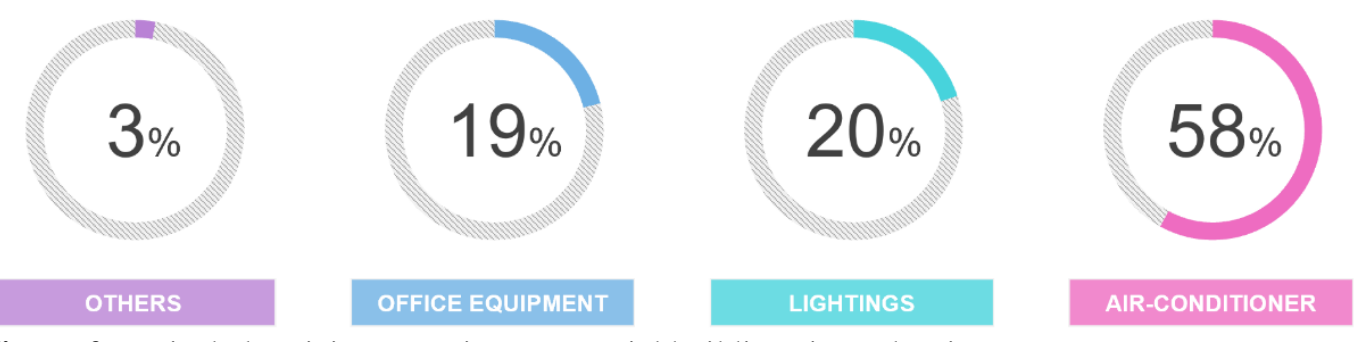

Figure 2 Typical electricity usage in commercial buildings in Malaysia

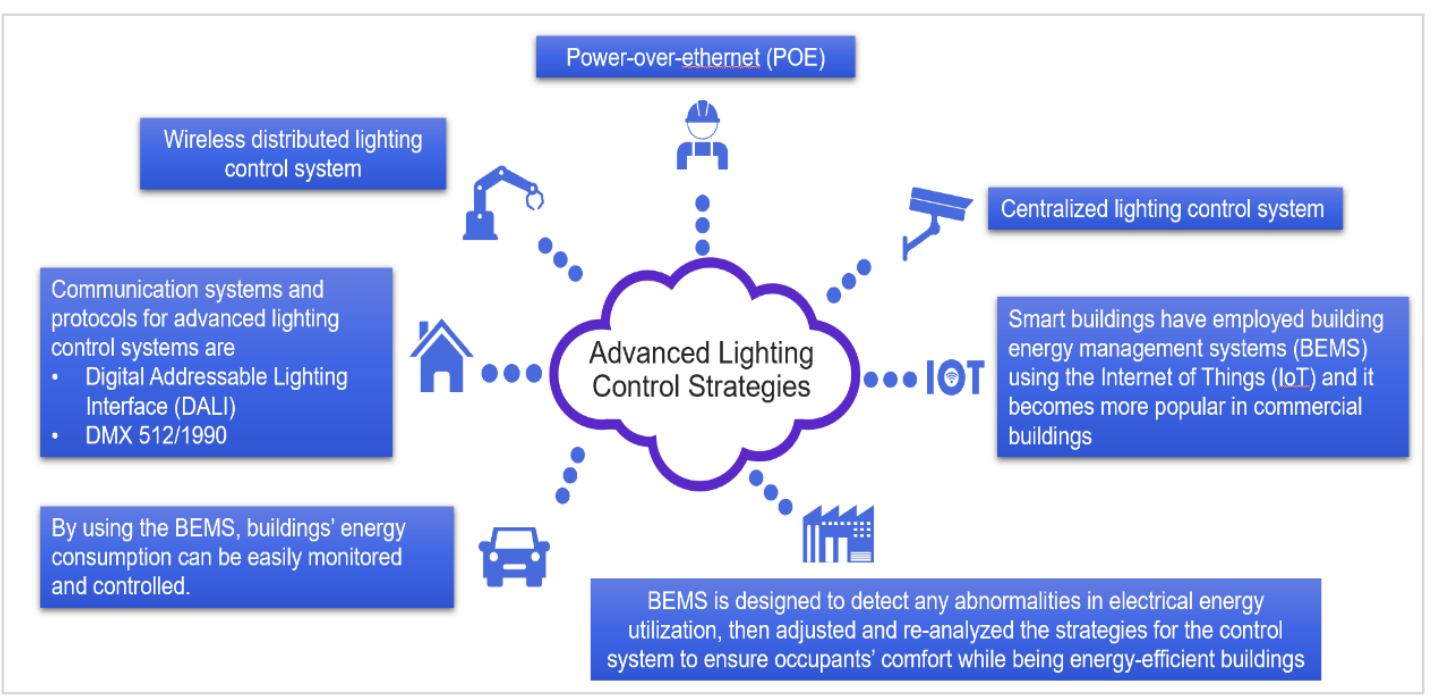

Figure 3 Advanced lighting control strategies 


\section{Literature reviews on lighting control system strategies}

About 20\% of commercial buildings have been installed with lighting control systems in 2015 due to the popularity of green building index (GBI) certification and the advancement of lighting control systems [20]. Installations of lighting control systems for new buildings' construction are higher than retrofitting lighting control systems with existing buildings [25]. There are three main approaches in building lighting control system which is by retrofitting energy-efficient lighting, improved lighting design practices, and improvements of lighting control system to reduce energy consumption while maintaining the occupants' visual comfort [26]. These are the building lighting control strategies with their influencing factors.

2.1Current trends and future challenges of occupant behavior towards energy efficiency awareness

The indoor illuminance can be focused to understand the behavior of building occupants' awareness in reducing electrical energy consumption [27]. Many methods have been introduced to predict the functional demand of lighting, the effect of manually and automatically lighting control systems toward occupants' control as tabulated in Table 1 [14, 28]. These research methods can identify occupant behavior for light switching in the office. Occupants' behaviors are based on the human decision-making process which is complex and has various influencing factors. Adaptive behaviors towards building energyefficient efforts can significantly decrease building energy consumption. However, the dissatisfaction of buildings' occupants towards these efforts may limit the reduction of building energy consumption [29]. Thus, building energy-efficient efforts must consider the needs and priorities of buildings' occupants to meet their satisfaction in achieving the energy savings target. To make the occupants feel comfortable, the occupants must have the possibility to control the system accordingly. Each occupant has specific preferences because of the specific tasks they are engaged in to avoid visual discomfort $[4,19,20]$. The ability to control the lighting system provides visual comforts to the buildings' occupants while increasing their productivity [17]. Nevertheless, current lighting control through manual switching may cause the buildings' occupants to forget turning off the lights when leaving the room and let the lamp turn on without any activity or presence of an occupant resulted in the inefficiency of cost and energy $[15,20]$. Therefore, cultivate energy-saving habits through repetitive behaviors will have the greatest effect on buildings' energy consumptions [30]. Building occupants' energy-saving behavior can be identified through these lighting usage pattern [27]:

1. When the occupant enters the office, will he or she turn on the light based on the daylight illuminance?

2. When the occupant stays in the office, will he or she turn off the light based on the indoor illuminance?

3. When the occupant leaves the office, will he or she turn off the light based on how long she or he leaves?

Table 1 Factors that affect occupant behavior towards lighting demand control options

\begin{tabular}{ll}
\hline \multicolumn{1}{c}{$\begin{array}{c}\text { Factors that affect occupant } \\
\text { behaviour }\end{array}$} & \multicolumn{1}{c}{ Methods for current lighting demand control options } \\
\hline Indoor illuminance [27] & $\begin{array}{l}\text { Effect of manually and automatically lighting control systems toward occupants' } \\
\text { control [14, 28] }\end{array}$ \\
\hline & $\begin{array}{l}\text { Energy-efficient efforts must consider the needs and priorities of buildings' occupants } \\
\text { to meet their satisfaction in achieving the energy savings target [14]. }\end{array}$ \\
\cline { 2 - 3 } Occupants' dissatisfaction [29] & $\begin{array}{l}\text { Each occupant has specific preferences because of the specific tasks they are engaged } \\
\text { in to avoid visual discomfort [4, 19, 20] }\end{array}$ \\
\hline \multirow{2}{*}{ Energy-saving habits [27] } & $\begin{array}{l}\text { Cultivate energy-saving habits through repetitive behaviors will have the greatest } \\
\text { effect on buildings' energy consumptions [30]. }\end{array}$ \\
\hline $\begin{array}{l}\text { Building occupants' energy-saving behavior can be identified based on lighting usage } \\
\text { pattern [27]. }\end{array}$ \\
\hline
\end{tabular}

2.2Comparative studies on current lighting control strategies

The current lighting control system consists of only wiring, lamps, and switches. It has low installation cost, and the users have direct control based on their personal preference of illumination. Though, it may lead to energy waste if the users have lack of energy efficiency awareness [20]. Thus, comparative studies 
have been done on current lighting control strategies which are presented in Table 2. Recently, lighting system is equipped with motion detection sensors to detect movement in certain areas such as corridors and car parks. The motion detection sensors will automatically turn on $100 \%$ of the lightings from only $30 \%$ lightings in that areas. Besides, the sensor can also be used when the occupant is detected, the light will turn on and turn off when the room is no longer occupied. By using this sensor, the building energy consumptions that can be reduced daily is $10.22 \%$ [21, 23]. However, sensing-based control strategies is unable to determine the number of occupants and the specific task that has been performed. The system will automatically turn on all the lights once the sensor detects any occupants [17]. Moreover, the manual switching on and off gives the highest reduction in energy consumption and provide more personal satisfaction towards occupants' visual comfort as compared to sensing-based lighting control system [31]. Occupants can turn on or off the lights when necessary and should be able to choose any illuminance level as desired using switches and dimmers. The main issue is to increase the energy efficiency awareness amongst the occupants to manually switch off the light when they leave the office. The simple lighting control system is usually implemented in existing buildings [20, 27]. However, the attitude of occupants in switching off manually the lights when they leave the room become the main obstacle in achieving the energy savings target. Thus, the automatic lighting system is the best solution for buildings' energy efficient practices.

Besides, automatic lighting control systems have more significant impact on the reduction of energy consumption due to the possibility of occupants' behavior that may cause energy waste [13]. To overcome the obstacle of occupants' behavior, the sensing-based control system has been introduced. The predicted occupancy control strategy (POCS) can reduce the operating hours of the lighting system based on time scheduling. This control strategy can schedule the switching on and off the lightings at specific times based on the building occupants' requirements. It will automatically turn off the lights during unoccupied period usually on the weekend and after working hours. Thus, this system can avoid energy waste due to lightings which are turned on during unoccupied period [14, 25]. Another sensingbased lighting control system is the Real Occupancy Control Strategy (ROCS) which is based on the presence of the occupancy. ROCS do not operate on based on time, but the system will turn on the lights when it detects the room is occupied, otherwise it will turn off the light when the room is unoccupied. A specified time delay can be programmed before turning off the lights to prevent the system to turn off the lights when the room is still occupied. This control strategy can be employed when the occupancy is unpredictable and unable to determine the specific schedule. Existing applications for this sensing-based lighting control system are private offices, toilets, corridors, stairways, and libraries [32, 33]. Besides, illuminance control is another example of a sensing-based control strategy such as a constant illuminance control strategy (CICS) that can control the illuminance level by considering the aging of the lighting system. When the illuminance level is too high, the system will reduce the lumen output of the lightings. If the illuminance level is too low, the system will increase the lumen output of the lightings. The system aims to make sure minimum lighting energy is being used and maintain a constant lighting level. On the other hand, the daylight harvesting control strategy uses light sensors with photocells to measure the illuminance level in the specific area. Daylighting is one of the critical aspects of building design and lighting control strategy as specified in EN12464-1 [13]. This control system operates in a similar mechanism with illuminance control (CICS). The light sensors are usually located in a large area and each light sensor will control a separate group of lightings to ensure uniform illuminance level throughout the area. The overview of the sensing-based lighting control strategies is shown in Figure 4 [14]. 


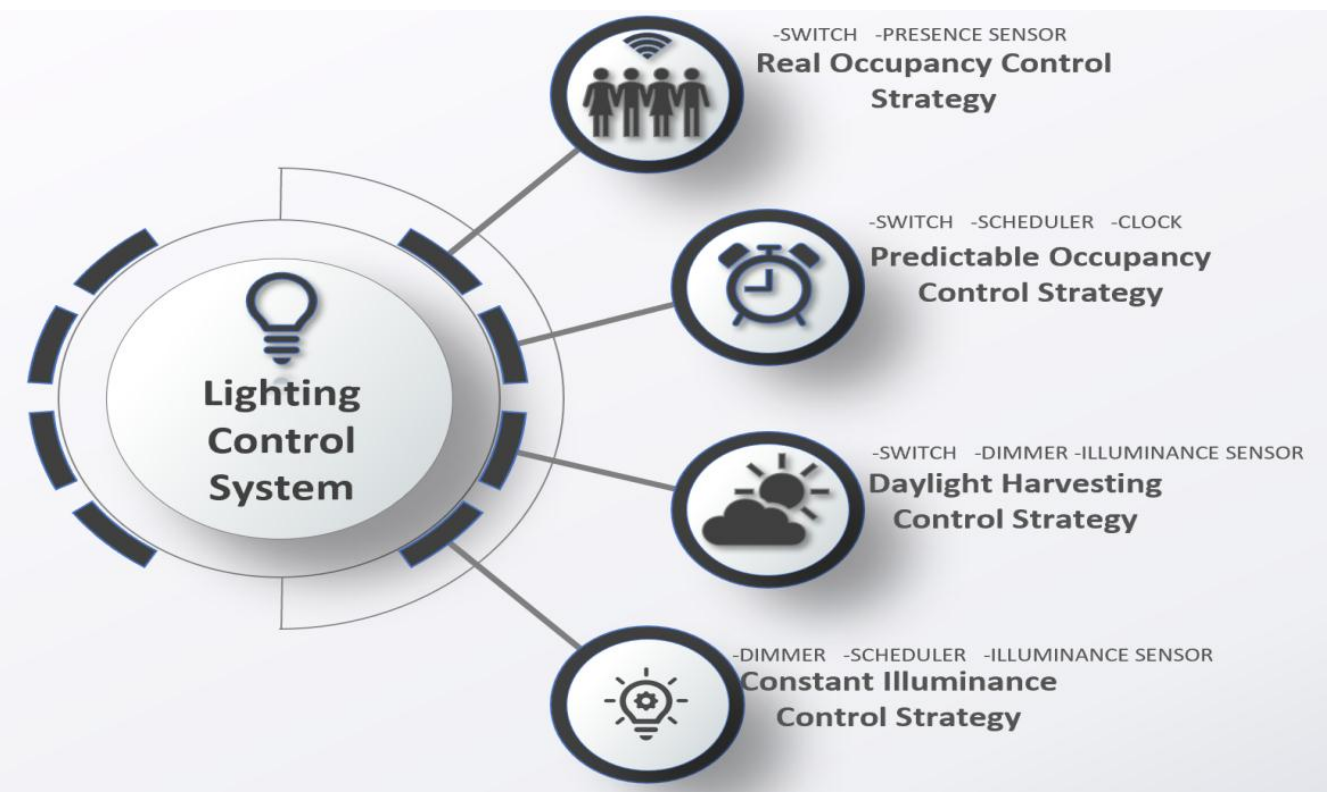

Figure 4 Sensing-based lighting control strategies

Table 2 Current trends of lighting control strategies

\begin{tabular}{|c|c|}
\hline $\begin{array}{l}\text { Current lighting control } \\
\text { strategies }\end{array}$ & Challenges and advantages \\
\hline $\begin{array}{l}\text { Manual control based on } \\
\text { personal preference of } \\
\text { visual comfort. }\end{array}$ & $\begin{array}{l}\text {-low installation cost. } \\
\text { •highest reduction in energy consumption. } \\
\text { •provide more personal satisfaction towards occupants' visual comfort as compared to sensing- } \\
\text { based lighting control system [31]. } \\
\text { •may lead to energy waste if the users have lack of energy efficiency awareness [20]. }\end{array}$ \\
\hline $\begin{array}{l}\text { Automatic lighting system } \\
\text { by using sensing-based } \\
\text { control strategies :- }\end{array}$ & $\begin{array}{l}\text { - best solution for buildings' energy efficient practices [13]. } \\
\text { • overcome the obstacle of occupants' behavior towards energy efficiency effort. }\end{array}$ \\
\hline 1.Motion detection sensors & $\begin{array}{l}\text {-to detect movement in certain areas such as corridors and car parks. } \\
\text { •building energy consumptions that can be reduced daily is } 10.22 \%[21,23] \text {. } \\
\text { •unable to determine the number of occupants and the specific task that has been performed [17]. }\end{array}$ \\
\hline $\begin{array}{l}\text { 2.Predicted occupancy } \\
\text { control strategy (POCS) }\end{array}$ & $\begin{array}{l}\text {-reduce the operating hours of the lighting system based on time scheduling } \\
\text { • avoid energy waste due to lightings which are turned on during unoccupied period }[14,25] \text {. }\end{array}$ \\
\hline $\begin{array}{l}\text { 3. Real occupancy control } \\
\text { strategy (ROCS) }\end{array}$ & $\begin{array}{l}\text {-based on the presence of the occupancy } \\
\text {-employed when the occupancy is unpredictable and unable to determine the specific schedule. } \\
\text {-Existing applications are private offices, toilets, corridors, stairways, and libraries }[32,33] \text {. }\end{array}$ \\
\hline $\begin{array}{l}\text { 4.Constant illuminance } \\
\text { control strategy (CICS) }\end{array}$ & g energy is being used and maintain a constant lighting level. \\
\hline $\begin{array}{l}\text { 5.Daylight harvesting } \\
\text { control strategy }\end{array}$ & $\begin{array}{l}\text { - uses light sensors with photocells to measure the illuminance level in the specific area. } \\
\text {-Daylighting is one of the critical aspects of building design as specified in EN12464-1 [13]. } \\
\text { •operates in a similar mechanism with illuminance control (CICS). }\end{array}$ \\
\hline
\end{tabular}

\subsection{Future trends of smart building lighting} systems

Smart building is one of vital elements in smart city concept. A smart building can provide intelligent facilities for building's occupants with better understanding on current building information through communication system such as humidity, temperature, lighting and weather [34]. A smart building lighting system in Figure 5 is also equipped 50 with Internet-of-Things (IoT) based smart lighting control systems to support the emerging trend of future smart buildings. The IoT based smart lighting control system is designed to improve the building energy efficiency through Building Energy Management System (BEMS) [21]. There are three conceptual layers approach for the smart lighting control system which consists of Layer 1 for sensing, delivery, and management layer, followed by Layer 2 
for processing and modelling and finally, Layer 3 for smart building services which in this case provide visual comfort towards buildings' occupants [22]. Information obtained from the lighting system will be the input for the illumination level, and linked with other facilities such as heating, ventilating and airconditioning (HVAC) control services [24, 35]. Thus, all these valuable data can be obtained through $\mathrm{Wi}-\mathrm{Fi}$ access and the information are available for further analysis on the building energy management control system to achieve energy-efficient building [13, 20].

Smart building is the combination of the architectural design, interior design, mechanical and electrical system to make sure all the control and automation systems are easily controlled without human interference [15]. The lighting system in a smart building can be operated in several different modes, which are Manual, Auto, and Hybrid for various applications [13]. The wireless sensor and actuator network will collect the data based on the use of smart personalized LED light of the occupants in the building [22]. The sensing, delivery, and management layer collect the data and provide it as inputs that are required from the sensors for the IoTs to become as an ecosystem. The main components are the sensors and actuators that can be selfconfigured and controlled through the Internet, different monitors, and available software. The common language and data model are needed to deal with the heterogeneity of the data source [36]. The sensors of lighting systems can be used to monitor the electrical energy consumption and provide data for the management to re-evaluate the lighting control strategies. Table 3 shows a comparison between the lighting control system in the existing building and smart building. There are several factors that have been identified for building energy efficiency improvement. As an example, existing buildings still use simple lighting control systems which are easily installed whereas smart building uses the IoT based BEMS including the smart lighting control system [20].

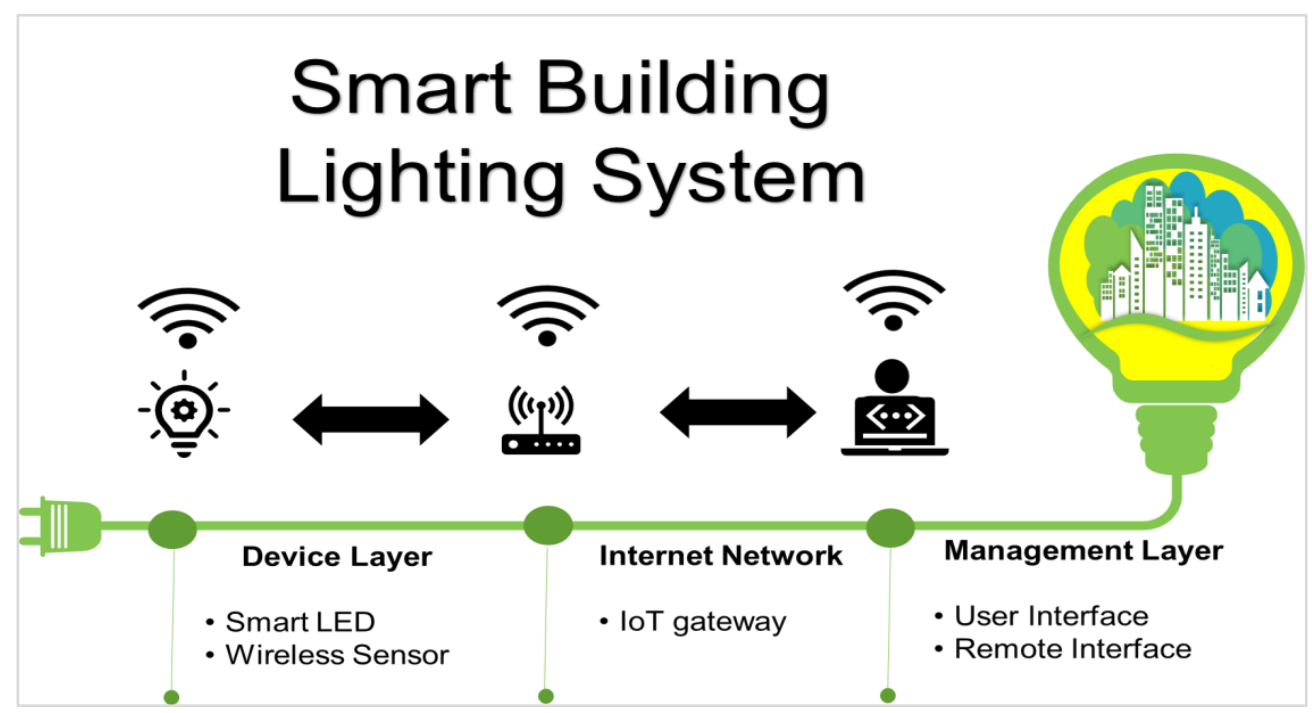

Figure 5 Lighting system in smart building

Table 3 Comparison between existing buildings with current lighting control system and smart building

\begin{tabular}{|c|c|c|}
\hline Parameters & Existing building & Smart building \\
\hline Installation cost & Low & High \\
\hline Building energy consumption & High & Low \\
\hline Operation mode & Manual & Auto and Hybrid \\
\hline $\begin{array}{l}\text { Monitoring of building energy } \\
\text { consumption }\end{array}$ & Difficult & Easy \\
\hline $\begin{array}{l}\text { System error severity and } \\
\text { maintenance }\end{array}$ & $\begin{array}{l}\text { Need human interference to locate the } \\
\text { error }\end{array}$ & $\begin{array}{l}\text { No human interference is needed to locate the } \\
\text { error }\end{array}$ \\
\hline Cyber-security & No effect & Severe effect \\
\hline
\end{tabular}




\section{Conclusions}

As the conclusion, the smart building uses a BEMS system resulting in high energy saving compared to the existing building that uses a simple lighting control system. BEMS combines effective sensors and energy consumption reduction strategies such as predictable occupancy control strategy, real occupancy control strategy, constant illuminance control strategy, and daylight harvesting control strategy with IoT application. Even though the smart building has higher installation cost, but it provides a significant reduction in building energy consumption and reduce the greenhouse effect. Soon, the smart building concept should be implemented in higher energy consumption buildings for more efficient building energy management.

\section{Acknowledgment}

The authors would like to acknowledge the support from the Internal Social Project Via Research (INSPIRE) Research Grant 2019 under a grant number of UniMAP/PPPI/9001-00584(1) from Universiti Malaysia Perlis.

\section{Conflicts of interest}

The authors have no conflicts of interest to declare.

\section{References}

[1] Abergel T, Dean B, Dulac J. Towards a zero-emission, efficient, and resilient buildings and construction sector: Global Status Report 2017. UN Environment and International Energy Agency: Paris, France. 2017.

[2] https://www.iea.org/reports/global-energy-review2020/global-energy-and-CO2-emissions-in-2020. Accessed 9 July 2020.

[3] Ahmad AS, Hassan MY, Abdullah H, Rahman HA, Majid MS, Bandi M. Energy efficiency measurements in a Malaysian public university. In international conference on power and energy 2012 (pp. 582-7). IEEE.

[4] Hassan JS, Zin RM, Abd Majid MZ, Balubaid S, Hainin MR. Building energy consumption in Malaysia: an overview. Jurnal Teknologi. 2014; 70(7): 33-8.

[5] Dudley B. BP statistical review of world energy. BP Statistical Review, London, UK.2016.

[6] https://www.mgtc.gov.my/annualreport2019/. Accessed 9 July 2020.

[7] Ministry of Energy, Green technology and water Malaysia. Green technology master plan Malaysia (2017-30).

[8] Mansur TM, Baharudin NH, Ali R. Optimal sizing and economic analysis of self-consumed solar PV system for a fully DC residential house. In international conference on smart instrumentation, measurement and application 2017 (pp. 1-5). IEEE.

[9] Ananda-Rao K, Ali R, Taniselass S, Baharudin NH. Microcontroller based battery controller for peak shaving integrated with solar photovoltaic. 4th IET clean energy and technology conference 2017.

[10] https://www.iea.org/policies/124-national-energyefficiency-action-plan-4-2017-2020. Accessed 9 July 2020.

[11] Tenaga S. Guidelines on no-cost and low-cost measures for efficient use of electricity in buildings. Suruhanjaya Tenaga (Energy Commission). 2014.

[12] File M. Commercial buildings energy consumption survey (CBECS). US Department of Energy: Washington, DC, USA. 2015.

[13] Wagiman KR, Abdullah MN, Hassan MY, Radzi NH. A review on sensing-based strategies of interior lighting control system and their performance in commercial buildings. Indonesian Journal of Electrical Engineering and Computer Science. 2019; 16(1):20815.

[14] Imam MT, Afshari S, Mishra S. Smart lighting control systems. In intelligent building control systems 2018 (pp. 221-51). Springer, Cham.

[15] Firdaus R, Mulyana E. Smart building lighting system. In IOP conference series: materials science and engineering 2018 (pp. 1-7). IOP Publishing.

[16] Steg L, Dreijerink L, Abrahamse W. Factors influencing the acceptability of energy policies: a test of VBN theory. Journal of Environmental Psychology. 2005; 25(4):415-25.

[17] Xu L, Pan Y, Yao Y, Cai D, Huang Z, Linder N. Lighting energy efficiency in offices under different control strategies. Energy and Buildings. 2017; 138:127-39.

[18] Mahlia TM, Razak HA, Nursahida MA. Life cycle cost analysis and payback period of lighting retrofit at the university of Malaya. Renewable and Sustainable Energy Reviews. 2011; 15(2):1125-32.

[19] Dubois MC, Bisegna F, Gentile N, Knoop M, Matusiak B, Osterhaus W, et al. Retrofitting the electric lighting and daylighting systems to reduce energy use in buildings: a literature review. Energy Research Journal. 2015; 6(1):25-41.

[20] Pandharipande A, Newsham GR. Lighting controls: evolution and revolution. Lighting Research \& Technology. 2018; 50(1):115-28.

[21] Jin X, Wang G, Song Y, Sun C. Smart building energy management based on network occupancy sensing. Journal of International Council on Electrical Engineering. 2018; 8(1):30-6.

[22] Kumar A, Kar P, Warrier R, Kajale A, Panda SK. Implementation of smart LED lighting and efficient data management system for buildings. Energy Procedia. 2017; 143:173-8.

[23] Alam MR, Reaz MB, Ali MA. A review of smart homes - past, present, and future. IEEE Transactions on Systems, Man, and Cybernetics, Part C (Applications and Reviews). 2012; 42(6):1190-203.

[24] Ma X, Cui R, Sun Y, Peng C, Wu Z. Supervisory and energy management system of large public buildings. In international conference on mechatronics and automation 2010 (pp. 928-33). IEEE. 
[25] Ui Haq MA, Hassan MY, Abdullah H, Rahman HA, Abdullah MP, Hussin F, et al. A review on lighting control technologies in commercial buildings, their performance and affecting factors. Renewable and Sustainable Energy Reviews. 2014; 33:268-79.

[26] Roohi MH, Khorsandi A, Setayesh A, Eslamieh A, Saidi H. Design and implementaion of smart building lighting system. In international congress on electric industry automation 2015 (pp. 7-10). IEEE.

[27] Wang C, Yan D, Ren X. Modeling individual's light switching behavior to understand lighting energy use of office building. Energy Procedia. 2016; 88:781-7.

[28] Labeodan T, De Bakker C, Rosemann A, Zeiler W. On the application of wireless sensors and actuators network in existing buildings for occupancy detection and occupancy-driven lighting control. Energy and Buildings. 2016; 127:75-83.

[29] Paone A, Bacher JP. The impact of building occupant behavior on energy efficiency and methods to influence it: a review of the state of the art. Energies. 2018; 11(4):1-19.

[30] Azizi ZM, Azizi NS, Abidin NZ, Mannakkara S. Making sense of energy-saving behaviour: a theoretical framework on strategies for behaviour change intervention. Procedia Computer Science. 2019; 158:725-34.

[31] Gilani S, O'Brien W. A preliminary study of occupants' use of manual lighting controls in private offices: a case study. Energy and Buildings. 2018; 159:572-86.

[32] Atayero AA, Popoola SI, Takpor T, Badejo JA. Occupancy controlled lighting system for smart buildings. Proceedings of the world congress on engineering and computer science. 2017.

[33] Mohamed RR, Mohamed MA, Azmi K, Rao E, Hashim W. Indoor smart lighting controlling using human detection. International Journal of Advanced Trends in Computer Science and Engineering. 2020; 9(1.1):566-70.

[34] Asri NA, Ibrahim R, Jamel S. Designing a model for smart city through digital transformation. International Journal of Advanced Trends in Computer Science and Engineering. 2019; 8(1.3):345-51.

[35] Aghemo C, Virgone J, Fracastoro GV, Pellegrino A, Blaso L, Savoyat J, et al. Management and monitoring of public buildings through ICT based systems: control rules for energy saving with lighting and HVAC services. Frontiers of Architectural Research. 2013; 2(2):147-61.

[36] Hernández-Ramos JL, Moreno MV, Bernabé JB, Carrillo DG, Skarmeta AF. SAFIR: secure access framework for IoT-enabled services on smart buildings. Journal of Computer and System Sciences. 2015; 81(8):1452-63.

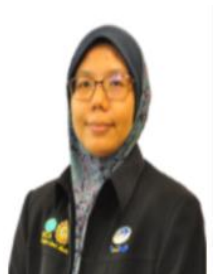

Nor Hanisah Baharudin received the B.E., MEng.Sc and Ph.D. degree in electrical engineering from PETRONAS University of Technology, Malaysia, Curtin University of Technology, Australia and Universiti Malaysia Perlis in 2005, 2008 and 2018 respectively. She is currently working with Universiti Malaysia Perlis. Her research interests include Renewable Energy, Energy Efficiency, Power Quality, and Design of Custom Power Devices.

Email: norhanisah@unimap.edu.my

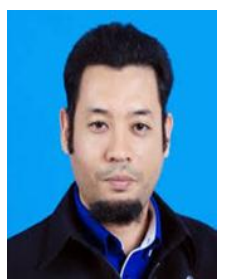

Tunku Muhammad Nizar Tunku Mansur received the B.E. and MEng.Sc degree in electrical engineering from PETRONAS University of Technology, Malaysia and Curtin University of Technology, Australia in 2002 and 2008, respectively. He is currently working with Universiti Malaysia Perlis. His research interests include Renewable Energy, LVDC, and Energy Management

Email: tunkunizar@unimap.edu.my

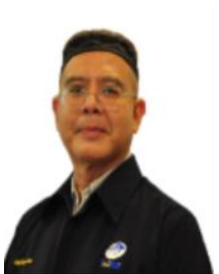

Rosnazri Ali received his B.Eng.(Electrical) from Royal Melbourne Institute of Technology in 1988, M.Sc.(Electrical) from Universiti Sains Malaysia in 2008 and PhD (Electrical) from Universiti Malaysia Perlis in 2014. His major interest of research includes Renewable Energy, Energy Efficient Systems and Power Electronics.

Email: rosnazri@unimap.edu.my

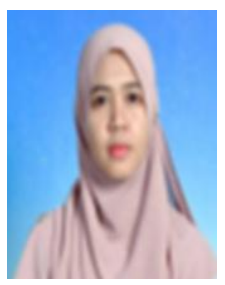

Nur Fatini Ahmad Sobri received his B.Eng.(Electrical) from Universiti Malaysia Perlis in 2018. She is currently pursuing her M.Sc. degree (Electrical) at Universiti Malaysia Perlis. Her major interest of research includes Renewable Energy, Power Quality and Custom Power Devices

Email: nurfatiniahmad7@gmail.com 